\title{
25 Research Suare \\ Quantitative determination of energy potential of refuse derived fuel from the waste recovered from Indian landfill
}

\section{R Sankar Cheela}

Indian Institute of Technology Kharagpur and Curtin University (Perth) https://orcid.org/0000-00032533-6697

\section{Michele John}

Curtin University

Brajesh Dubey ( $\nabla$ bkdubey@civil.iitkgp.ac.in )

Indian Institute of Technology Kharagpur and Curtin University (Perth) https://orcid.org/0000-00026991-7314

\section{Research}

Keywords: Landfill recovered waste, Refuse derived fuel, Energy recovery, Incineration, Municipal solid waste, Calorific value, Plastic waste

Posted Date: October 26th, 2020

DOl: https://doi.org/10.21203/rs.3.rs-62831/v2

License: (1) This work is licensed under a Creative Commons Attribution 4.0 International License. Read Full License

Version of Record: A version of this preprint was published at Sustainable Environment Research on July 20th, 2021. See the published version at https://doi.org/10.1186/s42834-021-00097-5. 


\section{Abstract}

Landfills are urban stocks and resource reservoirs for potential energy recovery. The purpose of this study is to evaluate the amount of energy that could be recovered from aged waste (around 5 - 20 years old) recovered from landfills. Investigations were conducted on the physical and chemical properties of refuse-derived fuel (RDF) prepared from recovered landfill waste (RLW) in Andhra Pradesh, India. Waste characterization studies included determination of waste composition, proximity analysis, ultimate analysis, and energy content. The moisture content ranged between 25.70 to $31.30 \%$, however, no trend was observed with age. In the ultimate analysis, the percentage of carbon increased from $42.94 \%$ to $71.66 \%$ with the age of the samples, this is due to an increase in the plastic content over time. The calorific value of the recovered landfill waste ranged from $10.35 \mathrm{MJ} / \mathrm{kg}$ to $21.83 \mathrm{MJ} / \mathrm{kg}$. From the findings, it can be summarized that the RDF can potentially be utilized as a feedstock for the recovery of energy from RLW. The results from this study will assist policy makers and local authorities in designing and developing strategies for resource and energy recovery from landfills in different urban cites across the globe.

\section{Introduction}

The amount of solid waste generated globally is expected to increase from 2.01 billion tons in 2016 to 3.40 billion tons by 2050 [1]. Population growth, rapid urbanization, demographic transfers, living habits, industrial, and economic developments are contributing factors to the increase in waste generation trends [2]. The handling, processing, treatment, and disposal of waste plays a vital role in development of good solid waste management systems [3]. In developing countries, it is estimated that municipal governments spend $20-50 \%$ of their annual budget on solid waste handling and management [1]. The cost benefit matrix in terms of resource recovery from solid waste is currently negative. It is also estimated that 80 $90 \%$ of waste in BRICS countries ends up in unlined landfill.

In Figure 1 shows the waste generation and disposal rates in BRICS countries. The per capita generation rate is highest in Brazil with $378 \mathrm{~kg} \mathrm{Cap}^{-1} \mathrm{yr}^{-1}$ and the lowest is in India with $183 \mathrm{~kg} \mathrm{Cap}^{-1} \mathrm{yr}^{-1}$. In Brazil and South Africa, $100 \%$ of the waste collected is dumped landfill. In India $91 \%$, Russia $95 \%$ and China $79 \%$ of waste is disposed in a landfill [4]. Disposal of municipal solid waste via unlined landfill is a common practice in low income and low-middle income countries. In unlined landfill waste is disposed in an unregulated approach leading to environmental and health hazards. In China, approximately 3 billion ton of municipal solid waste (MSW) is disposed of to landfills over the last 30 years. The Chinese national twelfth five-year plan of MSW treatment and management indicated a budget of 3.4 billion US Dollar for landfill eco-remediation projects in China from 2011 to 2015 [5]. In Germany, about 2.5 billion ton of MSW have been disposed of to landfills since 1975. It is estimated that 250 million tons of combustible material, 26 million tons of iron, 0.85-1.2 million tons of copper and 0.5 million tons aluminum can be recovered from these landfills [6]. The waste dumped in the landfills should be 
considered as an urban stock and resource reservoir for future resource recovery [7]. In India, 62 million tons of waste is generated in the year $2016,70 \%$ of waste generated is collected of which $22-28 \%$ is treated and the rest disposed of in landfills. With the present rate of dumping an area of about 1240 hectares is required to dispose of waste in India alone $[8,9]$.

The development of new landfill poses a critical challenge for local authorities (municipal councils) and regulatory bodies given to economic constraints, environmental policies, and opposition from the community and scarcity of land resources. Councils are encouraged to plan and develop systems like source segregation, recycling, and energy recovery to reduce the environmental burden and increase the lifespan of landfill. An important challenge and critical job for councils is also the aftercare management of the closed landfill [10-15]. Characteristics and composition of landfill waste, geological and geotechnical properties, topography, climatic conditions and ground water flow conditions play a major role in the development of a management plan for landfill aftercare management. The lack of detailed records and databases pose a critical challenge in development of the management plan for leachate, odor, heavy metals, and methane control systems in developing countries [16].

Policies and environmental laws are being developed to create a methodology to extract resources and energy from the existing landfills $[17,18]$. In India, consumption of energy has increased by $129 \%$ between 2000 and 2016. The forecasted annual growth rate of energy for India based on single-linear model to be $4.49 \%-5.21 \%$ from 2017 to 2026 [19]. The energy mix of India is comprised of coal (69\%), hydro-power (14\%), natural gas (10\%), oil (4\%), nuclear (2\%), and renewable (1\%). Energy demand is expected to double by 2035 , posing a critical challenge on the sources, generation and supply of additional energy [20]. Global electricity production in 2016 , increased by $2.9 \%$ reaching $25,082 \mathrm{TWh}$. Combustible fuels accounted for $67.4 \%$ of the total electricity production mix with $65.1 \%$ from fossil fuels and $2.3 \%$ from biofuels and waste. The remaining $32.6 \%$ came from hydroelectric plants $(16.6 \%)$, nuclear power plants (10.4\%), wind, tide, solar and other sources (5.6\%). China (24.8\%) and United States (17.2\%) together account for $40 \%$ of total global electricity production. India (5.9\%), Russian Federation (4.4\%), Japan (4.2\%), Canada (2.7\%), Germany (2.6\%), Brazil (2.3\%), Korea (2.2\%) and France $(2.2 \%)$ including China and USA account for two-thirds of the global electricity generation [21]. In USA, electric power (37.1\%), transportation (28.1\%), industry (21.9\%), residential and commercial uses $(10.4 \%)$ are the major electricity consumption sectors [22].

A waste hierarchy was developed in India for efficient utilization of resources and to evaluate waste management systems to achieve the objectives of Waste Avoidance and Resource Recovery Act 2001. The waste hierarchy focuses on reducing the waste reaching landfill through the application of the 3R's (reduce, reuse and recycle), source segregation, and technical treatment of waste. Indian solid waste management (SWM) regulations (2016) emphasize investigating the bio-mining and bio-remediation potential of old landfills [23-25]. In landfill mining the old waste is excavated from the landfill sites for resource and energy recovery. Urban land reclamation, extraction of recyclables and waste derived fuels can be achieved through this process [25]. 
Landfill reclamation and mining research is being carried out globally to understand the technology, economic, and social constraints. Conceptual discussions, feasibility studies and pilot scale investigations are being performed to further understand the process of landfill mining for specified deposits. Composition and characterization analysis are performed on the excavated waste samples based on age and location and are assessed to determine the energy and material recovery potential [2632]. The waste composition in municipal solid waste landfill typically consists of $50-60 \%$ of soil-type material, $20-30 \%$ combustible components, $10 \%$ inorganic components, and a small amount of metals. The variation in the waste compositions from different landfill sites indicates that site specific investigations should be performed to quantitatively determine the material and energy recovery potential $[7,32]$. The objective of this study is to determine the physico-chemical characteristics of the different aged-waste samples recovered from the landfill. Investigate the energy potential for refuse derived fuel (RDF) prepared from the combustible component to be utilized as a feed stock in thermal based waste to energy technologies.

\section{Study Area}

The investigations were conducted in a landfill facility located $22 \mathrm{~km}$ away from Visakhapatnam city in Andhra Pradesh state, India, covers an area of about 38.5 hectares. The landfill is an unlined facility receiving 1250 MT of solid waste on average per day. The landfill is in a small valley, surrounded by hills on three sides and a housing estate on the other. The landfill is $0.5 \mathrm{~km}$ away from a national highway $(\mathrm{NH}-16)$ and it is within $5 \mathrm{~km}$ radius of a coastal zone (Bay of Bengal). Waste has been dumped at this unlined landfill site for the past 20 years. The average depth of the waste heap from the top of the waste varies from 10 to 12 meters in the sample collection area. The study area and sampling locations are shown in Figure 2.

\subsection{Sample collection}

The sample collection methodology was determined in accordance with American Society for Testing and Materials (ASTM) D6009-12 (Sampling Waste Piles) [33] and the number of samples was determined as per ASTM D5321-92 (Reapproved in 2016) [34]. The location for the sample collection was determined through personal interview with the working staff. The samples were collected based on the age of the waste from the sample locations. Figure 2 represents the satellite imagery of the landfill and sample collection area. The age of the waste in sampling location L1 (Shown in Fig. 2), varies between 10 to 15 years (S1). The age of the waste in sampling location L2 varies between 5-10 years (S2) and in L3 is less than five years (S3). A trenching method was followed to collect the samples from the different depths. Trenches were dug using a bulldozer with a backhoe loader. The height of the waste heap varied between 10 to $12 \mathrm{~m}$ in all the three sampling locations. Initially the top layer containing soil and plants were removed to a depth of $0.20 \mathrm{~m}$. At every sampling location, 18 samples of $10.0 \pm 0.2 \mathrm{~kg}$ each were collected from three depths at a step interval of $2 \mathrm{~m}$. Overall, $500 \pm 25 \mathrm{~kg}$ sample was collected for each sampling location. This process of sampling was adopted to replicate the field practices being followed by a collaborating firm associated with council in the development of a waste-to-energy plant. 


\subsection{Refuse derived fuel sample preparation}

The samples collected were initially sieved through the $4.75 \mathrm{~mm}$ sieve segregate the inert material. Retained sample waste mixed and placed in hot air oven for a period of $24-48 \mathrm{~h}$ at $70 \pm 2{ }^{\circ} \mathrm{C}$ temperature. Dried samples were sieved in a mechanical sieve shaker for $15 \mathrm{~min}$ and further hand sorted to segregate the waste into different components. The components are inert material (soil and stones), combustibles (plastics and textile), inorganic (ceramics and glass, metal), and others (wood, coconut residues and bones). The weight of each component was then determined and a pie chart for physical composition of waste samples was developed. The representative RDF samples (S1) and (S2) were prepared from the combustible component representing 10-15-year-old samples and 05-10-year-old samples. An RDF sample (S3) representing 0-5-year aged sample was prepared by mixing combustible components (plastic and textiles) and coconut residues. The samples were shredded to achieve a size of $1.0 \pm 0.5 \mathrm{~cm}$ to perform the experimental studies. All the experiments were performed in triplicates for each sample and the average results were reported. The initial sample (sample from landfill) and final sample (prepared for sample analysis) are shown in Figure 3.

\subsection{Analysis methods}

Proximity analysis was performed to determine the volatile solids, fixed solids and ash content. Moisture content, of the samples was determined in in accordance with ASTM E1756-08 [35]. During sampling process, nine samples of $1 \mathrm{~kg}$ each were collected using stratified random sampling procedure to prepare a representative sample for determining moisture content. The samples were packed and sealed to reduce the interaction with ambient environment. The samples were transferred to the laboratory within $2.5 \pm 0.5 \mathrm{~h}$ and placed in a hot air oven for a period of $24-48 \mathrm{~h}$ to determine the moisture content.

The volatile combustible matter was determined in accordance with ASTM E872-82 (2013) [36]. Silica crucibles containing the samples were covered with lids and they were placed in a thermostatically controlled muffle furnace at a temperature of $550 \pm 20{ }^{\circ} \mathrm{C}$ for a period of $120 \mathrm{~min}$ to determine the quantity of volatile solids. The ash content was determined in accordance with ASTM D1102-84 (2013) [37]. Silica crucibles without lids were placed in the muffle furnace at a temperature of $550 \pm 20^{\circ} \mathrm{C}$ for a period of $30 \mathrm{~min}$.

For the elemental analysis, the samples were shredded to a size less than $600 \mu \mathrm{m}$. The shredded samples were dried in a hot air oven at a temperature of $103 \pm 2{ }^{\circ} \mathrm{C}$ for a period of $24 \mathrm{~h}$ to remove the moisture content. The elemental composition of the sample was determined using a Euro Vector A3000 elemental analyzer. During sample preparation for elemental analysis, the attached soil-like material was removed and the samples were shredded both mechanically and manually to the desired size. The samples were mixed well to achieve a homogeneous nature. Systematic random sampling was used for preparing the final sample to ensure the presence of multi components. The mixed sample was spread over a petri dish and it was divided into four parts. From each part sample was collected to prepare final sample for analysis. The analysis was performed five times in triplicate for each representative sample. 
The calorific value of the samples was determined in accordance with ASTM E711-87 [38]. Pellets of weight $1.0 \pm 0.5 \mathrm{gm}$ were prepared from the RDF samples using a hand pelletizer. The pellets were then placed in an adiabatic bomb calorimeter. The initial temperature and the final temperature were recorded for the determination the energy content.

Heavy metal analysis was performed to determine the amount copper, lead and cadmium in the ash. About $0.5 \mathrm{~g}$ sample was acid digested using $\mathrm{HNO}_{3}$ and $\mathrm{HCL}$ acid mix (1:3 molar ratio). The digestion process was performed in accordance with procedure outlined in USEPA 3050B (1986). The final sample for analysis was prepared by passing digested sample through Whatman No.42 filter paper. The heavy metals were analysed using atomic absorption spectrophotometer.

\section{Results And Discussions}

\subsection{Moisture Content}

Moisture content for the three samples ranged between 25 to $31 \%$ and is represented in the Table 1 . Moisture content was high in sample S1 (30.92 \pm 0.58$)$ and lowest in the sample S3 (26.43 \pm 0.65$)$. It was observed that moisture content increased with age and depth of the samples. The sample collection was conducted during the pre-monsoon season. The weather conditions were humid and hot with an average temperature ranging between 35 to $40^{\circ} \mathrm{C}$. Initial showers occurred for a short duration. The moisture content value is associated with amount of precipitation, percolation of water in waste piles, water holding capacity, and degradation activity of the organic waste [7]. A two-way ANOVA test indicated that there is no significant difference $(p>0.05)$ in the moisture content obtained from the different age and depth samples.

For incineration, moisture content of the feedstock should be less than 45\% [39]. In India, the average moisture content was ranging from $31 \%$ to $65 \%$. The percentage varies due the composition, seasonal variations, and climatic conditions. During the incineration plant design for mixed waste, secondary pit has to be designed to drain leachate under gravity. The leachate has to be collected and treated for disposal or application on land. Comingling of wastes with different moisture content is an alternative approach for reducing moisture in waste. For the aged waste, the combustible components (plastic and textile) are contaminated with soil-type material. Pre-heating followed by cleaning systems should be designed remove moisture content and soil-type material. The percentage of moisture content is one of the critical parameters in the design of drying unit.

\subsection{Physical composition of the waste}

The mean percentage of waste composition (by dry weight) for the samples collected from the unlined landfill in the study area is represented in Table 2. It was observed that the soil-like material trends increase with the age of the sample. Drain silt and street sweeping waste are mixed with the waste leading to an increase in soil waste levels. High amount of ash is observed as the rag pickers at the dumping site burn the heaps of waste to recover metal and ferrous material. The plastic waste 
component of the waste also increases with the age of the waste. It was probably due to increase in the usage of the plastic products after 2000 [40]. The per capita plastic product consumption in India is estimated as $11 \mathrm{~kg}$ person ${ }^{-1}$ [41]. Plastic is one of the major components that can be harvested from a landfill. The plastic component mainly includes covers, wrappers and 3D films. Water bottles and recoverable plastics are being picked up by the rag pickers for recycling.

Glass, metal and ceramics are being collected by the rag pickers. The organic waste, paper, yard waste and other biodegradable wastes decompose under anaerobic conditions leading to the release of methane gas. In the aged samples $95 \%$ of the biodegradable component is decomposed. Table 2 also presents a comparative study on physical classification of the aged waste recovered from landfill. Twoway ANOVA showed a significant difference $(p<0.05)$ in soil-type material, plastics and textile among all waste samples. No significant difference $(p>0.05)$ between S1 and S2 was observed for glass, metal, and ceramics.

Composition of landfill waste varies based on geographic location, socio-economic conditions, dietary habits, seasonal variations, recycling rates, and informal sector activity. Designing a system based on the average composition values will reduce the efficiency of the plant. Physical composition of the landfill waste plays a pivotal role in designing a incineration unit to meet the needs of local conditions.

\subsection{Proximate analysis}

The proximate analysis results of the RDF samples are presented in Table 3. RDF sample (S1) had high volatile solids of $58.75 \pm(1.25) \%$ dry weight and low ash content of $11.58 \pm(0.31) \%$ dry weight and fixed carbon content of $3.24 \pm(0.65) \%$ dry weight as compared to other RDF samples. In the RDF samples the volatile matter ranged between $43 \%$ and $58 \%$ on a dry weight basis. The decrease in volatile matter from RDF Sample S1 to S3 suggest that the organic matter decreases with the age of the waste. Central pollution control board compiled a report on selection criteria for waste processing technologies [39]. For incineration, the volatile matter should be greater than 45\%. In RDF samples S1 and S2 the volatile matter is higher than $45 \%$ while in S3 sample the volatile matter is 2.5 to $4.0 \%$ less compared to the desired value. The ash content of the RDF samples ranged between 11 and $18 \%$ on a dry weight basis. The permissible range of ash content to achieve high efficiencies in mass burn incinerators recommended by US EPA is $5-15 \%$ (dry basis). In RDF samples S1 and S2 the ash content is within the range while in S3 sample the ash content is $13-18 \%$ higher that maximum permissible value. The fixed carbon ranged between 3 and $9 \%$ on a dry weight basis. The high percentage of fixed carbon indicates longer retention times for combustion in incinerator [43].

The volatile solids content of normal plastic (not landfill recovered) is $98.5 \%$, the ash content is $1.2 \%$ and the fixed carbon less than $0.1 \%$ [7]. In the present study, the representative samples of RDF were prepared without pretreatment for landfill mined plastic and textile components. The impurities attached to the surface are not completely removed. The inert material and impurities from the landfill recovered waste components can be reduced trough a suitable pre-cleaning method during the RDF sample preparation. 
This will increase the volatile solids, heating value and reduces the ash content of the RDF. Table 3 presents the results obtained and comparative analysis of proximate analysis. The results obtained in the present study are within the range obtained from other similar research. $[7,43]$.

\subsection{Ultimate analysis}

The ultimate analysis results of the RDF samples are presented in Table 4. RDF sample (S1) has a high percentage of carbon $71.66 \pm(13.74)$ dry weight as compared to other RDF samples due to the amount of plastic content. No trend was observed for the plastic waste with age of the samples. The amount of plastic content in the waste depends on the consumption rates, disposal practices and recycling systems in the urban cities. Site specific characterization studies provide in depth understanding on the plastic waste component across the globe. Compared to normal plastic waste, recovered plastic waste has lower carbon content attributed to the presence of impurities like soil, sand that are difficult to be cleaned.

In RDF samples S2 and S3 the percentage of sulphur was $24.56 \pm$ (3.04) and $32.98 \pm(10.47)$ on a dry weight basis. The values obtained in this study are representing a high value of sulphur content compared to the other studies in literature. The high amount of sulphur is attributed to the formation of oxides of sulphur, hydrogen sulphide and volatile malodorous organic compounds with the aerobic and anaerobic decomposition of the waste. During ageing process in landfill, organic material with low molecular weight are degraded and resistant material are converted to humus-like matter. In this, transformation process the redox buffer changes from reducing conditions to slightly oxidizing conditions creating a favorable condition for sulphide to dissolve. The leaching experiments showed that the sulphur content is high in aerated landfill compared to original landfill indicating dissolution of sulphide in landfill material is a slow process. Binding of sulphide with solid landfill material due to deposited sulphur is reported [44].

The percentage of oxygen in all the samples ranged from 9 to $12 \%$. The percentage of hydrogen and nitrogen was low. The percentage of hydrogen decreased with the age of the waste and no trend was observed in terms of nitrogen and oxygen content.

\subsection{Calorific Value}

The calorific value results of the RDF samples are presented in the Table 4. The High Heating Value (HHV) on a dry basis was found to be the highest for the RDF sample (S1) was $20.47 \pm(2.87) \mathrm{MJ} \mathrm{kg}^{-1}$ and lowest for the RDF sample (S3) was $11.09 \pm(0.71)$. The variations were due to the physical composition of the samples. Using Dulong's equation and elemental composition, HHV (theoretical) was determined for the RDF samples. The HHV (experimental) and HHV (theoretical) for the RDF sample (S3) were found to be matching. However, for the other two RDF samples a percentage variation of $5-15 \%$ was observed. As per SWM rules 2016, RDF samples prepared from solid waste are recommended to be utilized as fuel in incineration units, if the calorific value is greater than $1500 \mathrm{Kcal} \mathrm{kg}^{-1}$. In the present study, the calorific value of all the three RDF samples prepared from the waste recovered from landfill can be used as a feedstock in mass burn incineration plant. Table 5 presents the results obtained and comparative 
analysis of energy content. The results obtained in the present study are within the range obtained from similar research $[7,39]$. The calorific value of landfill recovered waste depends on the composition of the waste and percentage of impurities. In the present study, segregation of the waste in laboratory contributed to achieve high calorific value. However, pre-cleaning was not performed to simulate current field practices. The average calorific value of the plastic material is $43.55 \mathrm{MJ} \mathrm{kg}^{-1}$ [7]. The calorific values obtained in this study are low compared to the normal plastics. Segregation and pre-cleaning of recovered waste will increase the calorific value of the RDF. Development of pre-treatment systems involves high capital and operation costs and require skilled personal for operation and maintenance [45].

The recovered landfill waste can be utilized to develop RDF or directly incinerated to harness thermal energy using the advancements in current technologies. RDF can mix with sawdust, rice husk, plastic waste, and other combustible components in certain ratio to increase the calorific value of feedstock. According to previous researchers, thermal treatment options are economical compared to chemical recycling methods [7]. Life cycle assessment studies should be conducted on designed treatment systems to develop environmentally sound solution $[46,47]$.

\subsection{Heavy metal analysis in ash}

The amount of copper, lead and cadmium in the water extract of ash samples are shown in Table 6. The ash generated is disposed into the landfill located $4 \mathrm{~km}$ from the waste to energy unit. The landfill is single liner facility, precautionary measures to identify leaching of heavy needs to installed to protect soil and ground water from contamination. Assessment of heavy metals and chlorine content in ash and volatile gases plays a pivotal role in determining the application of RDF as source of fuel in industrial applications. The plastic material containing poly vinyl chloride (PVC) and non-organic slats contribute to the chlorides. The increased concentration of chlorine contributes to the operational challenges like clogging. Utilization of RDF as fuel in thermo-chemical conversion process with temperature more than $550^{\circ} \mathrm{C}$ converts the organic matter with PVC into hydro chloric acid in vapor. The presence of heavy metals in RDF contribute to variations in mechanical properties and reactivity characteristics. The major sources of heavy metals include leather, power wires, metal cans and scrap material [48].

\section{Conclusion}

The present study investigated the energy potential of landfill recovered waste based on the physicochemical characteristics of the waste. Based on physical composition, soil-like material, and plastic (waste plastic bags and foils) are the major components of the aged waste recovered from landfill. The moisture content and the percentage of contamination increased with the age of the waste. Comparing the physio-chemical characteristics of landfill mined waste with process input criteria, incineration of RDF is best possible thermal conversion approach. The RDF prepared form the combustible component (plastic and textile) and coconut shells can be utilized as fuel source with proper pre-cleaning. The volatile solids, ash content and energy content analysis highlights that the adoption of pre-cleaning techniques such as cleaning, drying, and sorting, must be implemented to remove the impurities on the 
surface of the recovered waste feed stock. The treatment technologies options (gasification, pyrolysis, hydrothermal carbonization) can be explored by using comingled feed stocks. Overall, landfills can be considered as resource reservoirs for future energy generation. Reclamation of the waste material from these landfills increases the life of the landfill and reduces the usage of non-renewable energy sources in energy production. Composition and characteristics of aged waste play a key role in designing the treatment systems for waste recovered from landfill.

\section{Declarations}

\section{Availability of data and materials}

Not applicable

\section{Competing interests}

The authors declare that they have no competing interests.

\section{Funding}

Not applicable

\section{Authors' contributions}

VRS has conducted field studies, laboratory analysis, interpretation and was the major contributor in writing the manuscript. MJ and BD analyzed and interpreted results and revised the manuscript. All authors read and approved the final manuscript.

\section{Acknowledgements}

The authors are thankful to Ministry of Human Resources and Development, Government of India, and Australian Government (CIPRS Scholarship) for financially supporting the research. Gratitude's to Sri. Harinarayana, Commissioner and Dr. Hemanth, Chief Medical Officer of Health, Visakhapatnam for according us permission and logistic support; Management and Dr KVL Raju, Principal, MVGR college of Engineering (Autonomous) for providing the laboratory facilities during the field study.

Acknowledgements are also due to Sandeep Prasad and Rajesh Kola for supporting us all throughout the laboratory testing and analysis.

\section{References}


1. World Bank. 2018 Article on Solid Waste Management. World Bank; 2019.

2. Johari A, Ahmed SI, Hashim H, Alkali H, Ramli M. Economic and environmental benefits of landfill gas from municipal solid waste in Malaysia. Renewable and Sustainable Energy Reviews. 2012;16:2907-2912.

3. Ogunjuyigbe ASO, Ayodele TR, Alao MA. Electricity generation from municipal solid waste in some selected cities of Nigeria: an assessment of feasibility, potential and technologies. Renewable and Sustainable Energy Reviews. 2017;80:149-162.

4. World Bank. 2012 Report on Municipal Solid Waste Management: Opportunities for Russia. World Bank; 2017

5. Zhou C, Gong Z, Hu J, Cao A, Liang H. A cost-benefit analysis of landfill mining and material recycling in china. Waste Management. 2015;35:191-198.

6. Rotheut M, Quicker P. Energetic utilisation of refuse derived fuels from landfill mining. Waste Management. 2017;62:101-117.

7. Zhou C, Fang W, Xu W, Cao A, Wang R. Characteristics and the recovery potential of plastic wastes obtained from landfill mining. Journal of Cleaner Production. 2014;80:80-86.

8. Cheela VRS, Dubey B. Review of applications of systems engineering approaches in development of integrated solid waste management for a smart city. In: Rathinasamy M., Chandramouli S., Phanindra K., Mahesh U, editors. Waster Resources and Environmental Engineering II. Springer, Singapore. 2019. p. 159-177.

9. Swathi TIS, Vijay VK, Ghosh P. Scenario of landfilling in India: Problems, Challenges and Recommendations. In: Hussain C. editor. Handbook of Environmental Materials management. Springer. 2018. p. 1-16.

10. Anju EP, Nagendra SMS, Indumathi MN. Environmental burden by an open landfill in urban India. Waste Management. 2019;85:151-163.

11. Turner AD, Beaven RP, Woodman ND. Evaluating landfill aftercare strategies: A life cycle assessment approach. Waste Management. 2017;63:417-431.

12. Brand E, de Nijs TCM, Dijkstra JJ, Comans RNJ. A novel approach in calculating site-specific aftercare completion criteria for landfills in the Netherlands: Policy developments. Waste Management. 2016;56:255-261.

13. Jeremy WF, Morris WFJ, Crest M, Barlaz MA, Spokas KA, Akerman A, Yuan L. Improved methodology to assess modification and completion of landfill gas management in the aftercare period. Waste Management. 2012;32:2364-2373.

14. Chung Y, Paik C, Kim YJ. Assessment of mitigation pathways of GHG emissions from the Korean waste sector through 2050. Sustainable Environment Research. 2018;28:135-141.

15. Islam S, Moniruzzaman SM. Simulation of sustainable solid waste management system in Khulna city. Sustainable Environment Research. 2019;29:1-8. 
16. Weng Y, Fujiwara T, Houng HJ, Sun C, Li W, Kuo Y. Management of landfill reclamation with regard to biodiversity preservation, global warming mitigation and landfill mining: Experiences from the AsiaPacific region. Journal of Cleaner Production. 2015;104:364-373.

17. Johansson N, Krooka J, Eklunda M. The institutional capacity for a resource transition-A critical review of Swedish governmental commissions on landfill mining. Environmental Science and Policy. 2017;70:46-53.

18. Damigos D, Menegaki M, Kaliampakos D. Monetizing the social benefits of landfill mining: Evidence from a Contingent Valuation survey in a rural area in Greece. Waste Management. 2016;51:119-129.

19. Wang Q, Li S, Li R. Forecasting energy demand in China and India: Using single-linear, hybrid-linear, and non-linear time series forecast techniques. Energy. 2018;161:821-831.

20. Shahbaz M, Mallick H, Mahalik MK, Sadorsky P. The role of globalization on the recent evolution of energy demand in India: Implications for sustainable development. Energy Economics. 2016;55:5268.

21. 2018 Report on IEA Atlas of energy. International Energy Agency; 2019.

22. 2018 Report on US Primary Energy Consumption by Source and Sector. USA: United States Energy Information Administration; 2019.

23. Cheela VRS, Uday S, Dubey B. Solid Waste Management: Policies, Implementation and Challenges. In: Sengupta D, Goel S, Dubey B, editors. Treatment and disposal of Solid and Hazardous Wastes. Springer. 2020. p. 201-210.

24. SWM Rules 2016, Solid Waste Management Rules 2016.http://www.moef.gov.in/sites/default/files/SWM\%202016.pdf .Accessed on November 10, 2019.

25. Kieckhäfer K, Breitenstein A, Spengler TS. Material flow-based economic assessment of landfill mining processes. Waste Management. 2017;60:748-764.

26. Wolfsberger T, Aldrian A, Sarc R, Hermann R, Höllen D, Budischowsky A, Zöscher A, Ragoßnig A, Pomberger R. Landfill mining: resource potential of Austrian landfills - evaluation and quality assessment of recovered municipal solid waste by chemical analyses. Waste Management and Resources. 2015;33:962-974.

27. Zhao L, Giannis A, Lam WY, Lin SX, Yin K, Yuan G, Wang JY. Characterization of Singapore RDF resources and analysis of their heating value. Sustainable Environment Research. 2016;26:51-54.

28. Frandegard P, Krook J, Svensson N, Eklund M. Resource and climate implications of landfill mining. Journal of Industrial Ecology. 2013;17:742-755.

29. Bosmans A, Vanderreydt I, Geysen D, Helsen L. The crucial role of waste to-energy technologies in enhanced landfill mining: a technology review. Journal of Cleaner Production. 2013;55:10-23.

30. Caicedo-Concha DM, Sandoval-Cobo JJ, Whiting K. An experimental study on the impact of twodimensional materials in waste disposal sites: What are the implications for engineered landfills?. Sustainable Environment Research. 2016;26:255-261. 
31. Chiemchaisri C, Charnnok B, Visvanathan C. Recovery of plastic wastes from landfill as refusederived fuel and its utilization in small gasification system. Bioresource Technology. 2010;101:1522-1527.

32. Prechthai T, Padmasri M, Visvanathan C. Quality assessment of mined MSW from an open landfill for recycling potential. Resources, Conservation and Recycling. 2008;53:70-78.

33. Standard guide for sampling waste piles. D6009-12. ASTM International West Conshohocken, PA; 2016

34. Standard test method for determination of the composition of unprocessed municipal solid waste. D5231-92. ASTM International West Conshohocken, PA; 2016

35. Standard test method for determination of total solids in biomass. E1756-08. ASTM International West Conshohocken, PA; 2015.

36. Standard test method for volatile matter in the analysis of particulate wood fuels. E872-82. ASTM International West Conshohocken, PA; 2013.

37. Standard test method for ash in wood. D. 1102-84. ASTM International West Conshohocken, PA; 2004.

38. Standard Test Method for Gross Calorific Value of Refuse-Derived Fuel by the Bomb Calorimeter. E711-87. ASTM International West Conshohocken, PA; 2004

39. 2016 Report on Selection Criteria for Waste Processing Technologies. India: Central Pollution Control Board; 2019.

40. 2011 Article on Plastic Consumption in India. India: Wealthy Waste; 2019

41. 2017 Report on Sustainable Infrastructure with Plastics. India: Federation of Indian Chambers Of Commerce \& Industry; 2019

42. Quaghebeur M, Ben L, Daneel G, Peter N, Yiannis P, Tom VG, Jeroen S. Characterization of landfilled materials: screening of the enhanced landfill mining potential. Journal of Cleaner Production. 2013;55:72-83.

43. Mboowa D, Quereshi S, Bhattacharjee C, Tonny K, Dutta S. Qualitative determination of energy potential and methane generation from municipal solid waste in Dhanbad (India). Energy. 2017;123:86-391.

44. Ostman M. Ageing Landfills-Development and Processes. [PhD dissertation]. Uppsala: Swedish University of Agricultural Sciences; 2008.

45. Aleluia J, Ferrao P. Assessing the costs of municipal solid waste treatment technologies in developing Asian countries. Waste Management. 2017;69:592-608.

46. Cheela VRS, Dubey B. Incorporation of Life Cycle Thinking in Development of Integrated Solid Waste Management Systems. In: Sengupta D, Goel S, Dubey B, editors. Treatment and disposal of Solid and Hazardous Wastes. Springer. 2020. p.127- 144.

47. Khoo HH. LCA of plastic waste recovery into recycled materials, energy and fuels in Singapore. Resources, Conservation \& Recycling. 2019;145:67-77. 
48. Shumal M, Jahromi ART, Ferdowsi A, Dehkordi SMMN, Moloudian A, Dehnavi A. Comprehensive analysis of municipal solid waste rejected fractions as a source of Refused Derived Fuel in developing countries (case study of Isfahan- Iran): Environmental Impact and sustainable development. Renewable Energy. 2020; 146: 404-413.

\section{Tables}

Table 1 Moisture content analysis of the aged waste recovered from landfill

\begin{tabular}{|lllll|}
\hline Parameter & Unit & S1 & S2 & S3 \\
\hline Moisture Content & $\%$ weight & $30.92 \pm(0.58)$ & $28.67 \pm(0.79)$ & $26.43 \pm(0.65)$ \\
\hline
\end{tabular}

Table 2 Physical classification of the aged waste recovered from landfills

\begin{tabular}{|llllllllll|}
\hline Location & \multicolumn{3}{l}{ Visakhapatnam, India } & \multicolumn{2}{l}{ Thailand [31] } & & & $\begin{array}{c}\text { Belgium } \\
{[42]}\end{array}$ & $\begin{array}{c}\text { Thailand } \\
{[32]}\end{array}$ \\
\hline $\begin{array}{l}\text { Age in years } \\
\rightarrow)\end{array}$ & $10-15$ & $5-10$ & $<5$ & 2 & 5 & 7 & 10 & $14-29$ & $3-5$ \\
\hline $\begin{array}{l}\text { Soil-like } \\
\text { material }\end{array}$ & 56.59 & 53.72 & 45.93 & 32.9 & 56.59 & 27.86 & 49.1 & $44(12)$ & 34 \\
\hline Paper & - & - & 2.33 & 4.09 & - & - & - & $7.5(6)$ & 3.3 \\
\hline Plastics & 23.08 & 18.62 & 16.86 & 36.75 & 24.64 & 44.83 & 35.34 & $17(10)$ & 31 \\
\hline Textile & 2.75 & 5.84 & 10.47 & 11.51 & 7.45 & 10.21 & 1.80 & $6.8(6)$ & 7.6 \\
\hline Glass & 4.40 & 4.26 & 3.49 & 1.79 & 4.03 & 1.21 & 4.79 & 1.3 & 6.5 \\
\hline Ceramics & 4.93 & 4.79 & 2.33 & 1.19 & 0.83 & 0.73 & 2.99 & - & - \\
\hline Metal & 4.95 & 4.26 & 2.91 & 1.79 & 1.66 & 3.34 & 4.19 & $2.8(1)$ & 6.4 \\
\hline Others & 3.30 & 8.51 & 15.70 & 10.01 & 4.80 & 11.83 & 1.80 & 16.7 & 11.3 \\
\hline “-" Not Detected & & & & & & & & & \\
\hline
\end{tabular}

Table 3 Proximate analysis of the aged waste recovered from landfills 


\begin{tabular}{|c|c|c|c|c|c|c|}
\hline \multirow[t]{2}{*}{ Parameter } & \multirow[t]{2}{*}{ Unit } & \multicolumn{3}{|l|}{ Present study } & \multirow[t]{2}{*}{ India [43] } & \multirow[t]{2}{*}{ China [7] } \\
\hline & & $S 1(n=9)$ & $S 2(n=9)$ & S3 $(n=9)$ & & \\
\hline Volatile Solids & $\%$ & $58.75 \pm(1.25)$ & $51.72 \pm(0.77)$ & $43.67 \pm(0.32)$ & 45.28 & $87.09 \pm 1.09$ \\
\hline Ash & $\%$ & $11.58 \pm(0.31)$ & $13.72 \pm(0.15)$ & $17.37 \pm(0.39)$ & 24.71 & $10.39 \pm 0.26$ \\
\hline Fixed Solids & $\%$ & $3.24 \pm(0.65)$ & $5.89 \pm(0.79)$ & $8.03 \pm(0.58)$ & 4.53 & $2.10 \pm 0.40$ \\
\hline
\end{tabular}

Table 4 Ultimate analysis of the aged waste recovered from landfills

\begin{tabular}{|llllll|}
\hline Parameter & Unit & $\mathbf{S 1}(\mathbf{n}=5)$ & $\mathbf{S 2}(\mathbf{n}=5)$ & S3 $(\mathbf{n}=5)$ & Literature [6] \\
\hline Carbon & $\%$ & $71.66 \pm(13.74)$ & $57.53 \pm(16.80)$ & $42.94 \pm(9.57)$ & $40-75$ \\
\hline Hydrogen & $\%$ & $0.87 \pm(1.95)$ & $1.54 \pm(2.86)$ & $2.35 \pm(2.16)$ & $4.9-9.8$ \\
\hline Nitrogen & $\%$ & $0.82 \pm(1.12)$ & $0.23 \pm(0.29)$ & $1.01 \pm(0.69)$ & $0.03-4.1$ \\
\hline Sulfur & $\%$ & $1.41 \pm(0.77)$ & $24.56 \pm(3.04)$ & $32.98 \pm(10.47)$ & $0.1-0.5$ \\
\hline Oxygen & $\%$ & 9.433 & 9.049 & 11.480 & - \\
\hline Value in parenthesis represent standard deviation & & \\
\hline
\end{tabular}

Table 5 Energy content analysis of the aged waste recovered from landfills

\begin{tabular}{|c|c|c|c|c|c|c|}
\hline \multirow[t]{2}{*}{ Parameter } & \multirow[t]{2}{*}{ Unit } & \multicolumn{3}{|l|}{ Present study } & \multirow[t]{2}{*}{ India [43] } & \multirow[t]{2}{*}{ China [7] } \\
\hline & & $S 1(n=3)$ & $S 2(n=3)$ & S3 $(n=3)$ & & \\
\hline HHV (Exp) & $\mathrm{MJ} \mathrm{kg}^{-1}$ & $20.47 \pm(2.87)$ & $16.83 \pm(1.58)$ & $11.09 \pm(0.71)$ & 10.7 & $44.75 \pm 1.18$ \\
\hline HHV (Th) & $\mathrm{MJ} \mathrm{kg}^{-1}$ & 22.5 & 19.63 & 11.81 & & \\
\hline
\end{tabular}

Table 6 Heavy metals analysis in ash

\begin{tabular}{|llllll|}
\hline Heavy metal & Unit & Copper & Cadmium & Lead & Zinc \\
Value & ${\mu \mathrm{g} \mathrm{L}^{-1}}^{105.8 \pm 32.1}$ & $1.8 \pm 0.9$ & $39.6 \pm 11.4$ & $166.2 \pm 36.5$ \\
\hline
\end{tabular}


Figures
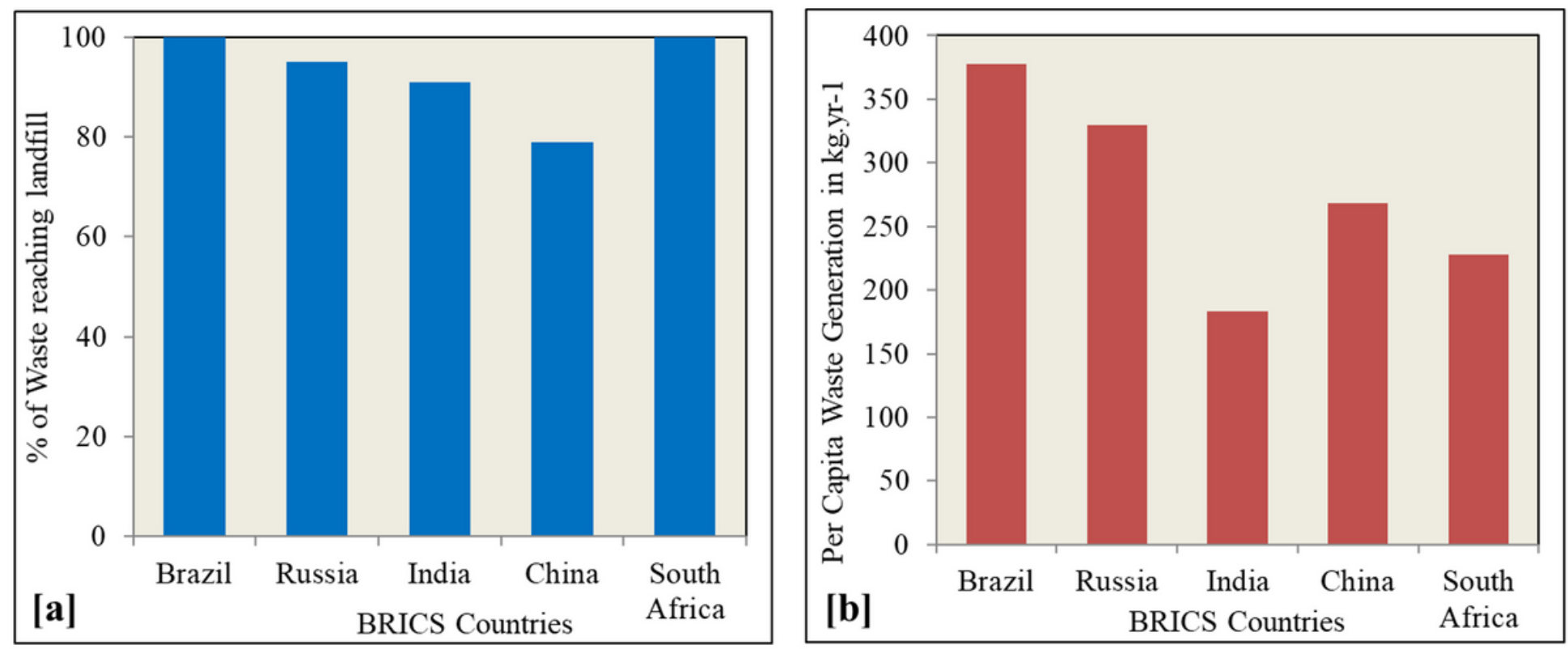

\section{Figure 1}

(a) Percentage of waste reaching landfill and (b) Per Capita waste generation in BRICS countries

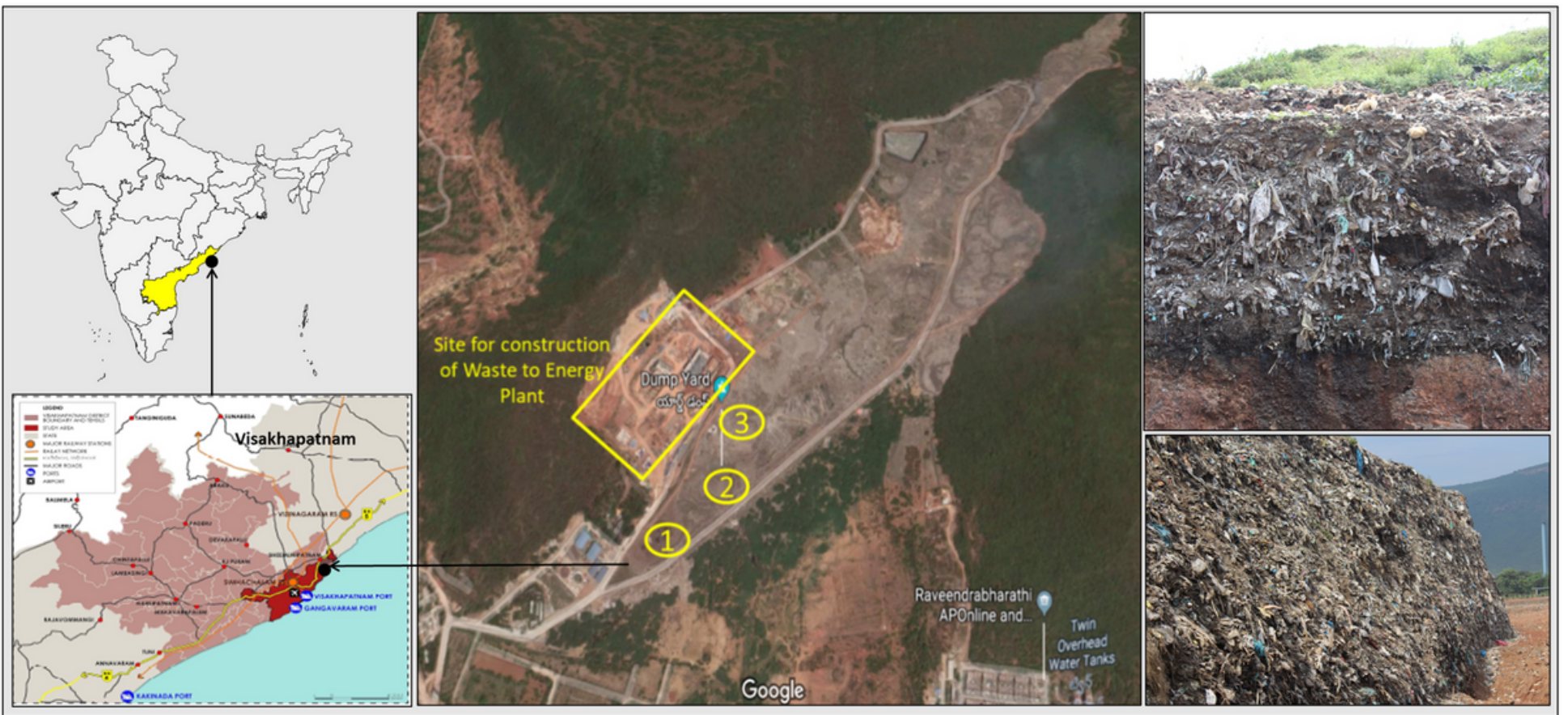

\section{Figure 2}

Study area and sampling locations in the landfill, Visakhapatnam city. Note: The designations employed and the presentation of the material on this map do not imply the expression of any opinion whatsoever on the part of Research Square concerning the legal status of any country, territory, city or area or of its 
authorities, or concerning the delimitation of its frontiers or boundaries. This map has been provided by the authors.
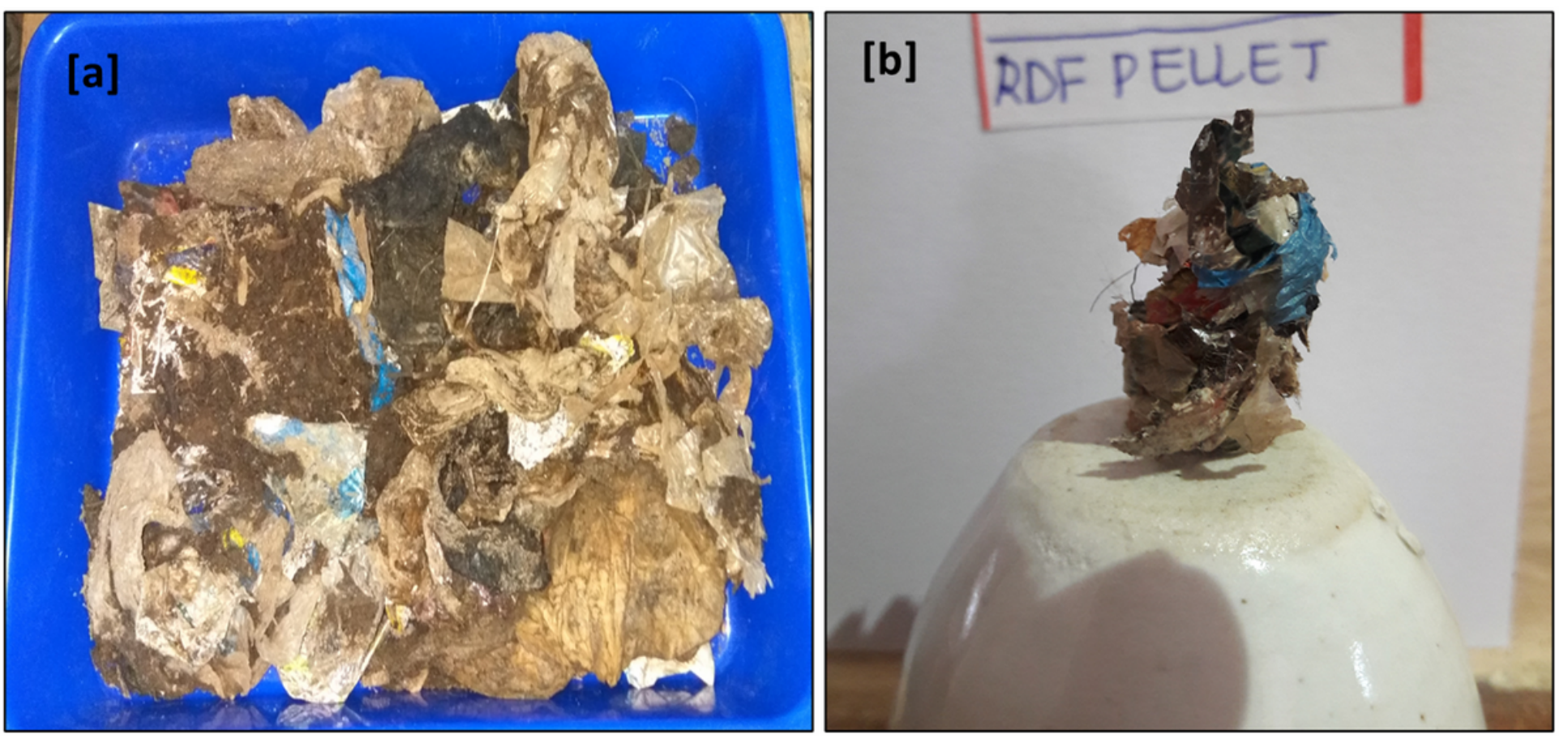

Figure 3

(a) Initial sample (sample from landfill) and (b) Final sample (prepared sample for analysis) 